\title{
Social Psychology and Public Support for Trade Liberalization
}

This study argues that a central factor in the determinants of citizen attitudes toward trade is the social psychology of the individual in question. Namely, we contend that the level of social trust an individual has will condition the degree to which an individual wants to open her country to imports from other countries. Those individuals with lower relative levels of social trust are less likely to support the notion of freer trade. We base this contention on the logic that those people who are distrustful of people in general are more likely to distrust that which comes from people who are unknown to them, such as goods coming into their country from abroad. This argument is a departure from previous studies of public attitudes toward trade, which have focused on various economic utilitarian considerations and xenophobia that shape citizen attitudes toward trade liberalization. To test our argument, we employ data from the 1995-1997 wave of the $W$ orld V alues Survey. Using a logit regression analysis, we find, as predicted, that the more social trust an individual has, the more likely that person is to support the idea of liberalized trade. 
Recent research has argued that an individual's level of cosmopolitanism also plays a role in support for free trade (Hainmueller and Hiscox 2006; Kaltenthaler et al. 2004; Mansfield and Mutz 2009). These studies have found that an individual's geographic self-identification, level of education, and attitudes toward people of different races helped condition whether she opposed or supported freer trade. Basically, this research shows that those individuals who are more cosmopolitan in their global outlook are more in favor of freer trade. Thus, support for free trade is not only about pocket book concerns but is very much about whether an individual feels comfortable with the idea of exchanging goods with people of a foreign culture.

While the work on cosmopolitanism and trade has made some crucial advances in our understanding of what motivates people to support or oppose more liberalized trade, we believe that this research has scratched the surface of what conditions attitudes toward trade. We argue that whether one is cosmopolitan or not comes down to one's basic social psychological predisposition toward others. In other words, one's view of human nature in general will shape how one thinks about economic exchange with others. This means that one's degree of social trust will play a large role in conditioning how much one supports the idea of trading with other countries.

This study will test this argument using a logit regression analysis employing data from the 1995-1997 wave of the $W$ orld V alues Survey. While there have been more recent waves of the $W$ orld V alues Survey since the wave we are using, none of the more recent waves include a question on trade. There is no reason to believe that the timing of the wave would affect the relationship between social trust and support or opposition to trade liberalization.

\section{Explanations of Public Preferences toward Trade}

Until recently, the most common way to conceptualize public support for trade liberalization was to focus on the economic impact trade would have on the individual in question (Baker 2003; Baron and Kemp 2003; Scheve and Slaughter 2001a; 2001b; Mayda 2006; Mayda and Rodrik 2005; O’Rourke and Sinnott 2002). These studies argued that where one sits in the economy determines if one is likely to support or oppose trade liberalization. This thesis has been tested in a series of studies of public attitudes toward trade 
liberalization. Scheve and Slaughter (2001a; 2001b), Mayda and Rodrik (2005), and Kaltenthaler et al (2004) have found that those with higher levels of human capital, ie, higher levels of education and thus skills are more supportive of free trade than those with lower levels of human capital. O'Rourke and Sinnott (2002) find that lower skilled occupations are less supportive of freer trade.

Other studies have identified groups that are more likely to support freer trade such as those with higher incomes (Hainsmueller and Hiscox 2009; Kaltenthaler et al 2004; Mayda and Rodrik 2005), higher social class status (Kaltenthaler et al 2004; Mayda and Rodrik 2005), not being a member of a union (Cline 1997; Hainmueller and Hiscox 2006; Kaltenthaler et al 2004; Mansfield and Mutz 2009; Mayda and Rodrik 2005; Mazur 2000; Moon 1996; O’Rourke and Sinnott 2001), women, and the young (Kaltenthaler et al 2004).

There is a small literature that relates one's ideology to support for trade liberalization. Trentmann (1988) argues that those who support free trade do so out an ideological commitment that it promotes the collective good.

More recently, the argument has been advanced that one's relative level of cosmopolitanism plays a key role in shaping preferences toward trade (Hainmueller and Hiscox 2006; Kaltenthaler et al 2004; Mansfield and Mutz 2009). Hainmueller and Hiscox (2006) have argued that one's level of education determined how cosmopolitan one would be. Kaltenthaler et al (2004) found that a more parochial a person is (i.e. the more local their sense of political attachment) the less likely that person is to support trade liberalization. Mansfield and Mutz (2009) posit that opposition to free trade is driven by "out-group" anxiety ,i.e., ethnocentrism.

While the literature that focuses on cosmopolitanism has added a much needed emphasis on the social psychology of trade preferences, it has failed to grapple with one of the most important potential psychological determinants of support for trade liberalization, a person's attitude about basic human nature. We explore this further in the section to follow. 


\section{The Argument: Views of Human Nature and Free Trade Support}

Myriad analyses of foreign policy attitudes have argued over the years that the public, in every country that has been studied, is not well informed about foreign policy issues (Almond 1950; Converse 1964). Subsequent studies found that foreign policy attitudes are more structured than originally assumed (Aldrich et al 2006; Feaver and Gelpi 2003; Feldman 1988; Gelpi, Feaver, and Reifler 2006; Hurwitz and Peffley 1987; Hurwitz, Peffly, and Seligson 1993; Wittkopf and Maggiotto 1981; Shamir and Arian 1994), but those attitudes are not based on highly developed mental models that tie complex aspects of foreign policy issues together but are driven by core values, which are very broad and basic predispositions toward foreign policy issues.

Wittkopf (1990) developed a very useful typology for understanding and categorizing members of the public as they consider issues in foreign relations from their core values. He split the public along a dimension on foreign policy issues, from militant internationalism to cooperative internationalism. Militant internationalism refers to views focused on the dangers presented by other nations. The cooperative internationalism dimension assumes that all nations need not be viewed as potential threats at all times.

The core value that is most likely to determine whether one is likely to view the world from a militant internationalist or cooperative internationalist perspective is an individual's sense of trust in other people. While others have argued that aspects of an individual's psychology will condition their attitudes toward trade (Baron and Kemp 2004; Jacob et al. 2011; Kemp 2008), this is the first research to argue that an individual's relative level of social trust will condition how she views trade liberalization.

Generalized trust in other people will allow for trust in other nations that is known as international trust (Brewer and Steenbergen 2002). This level of trust in other countries is essentially a product of the view one has of basic human nature. People who do not trust others in their own ethnic and social group are particularly unlikely to trust foreigners (Binning 2007; Brewer et al 2004; Brewer and Steenbergen 2002; Citrin and Sides 2008; Herreros and Criado 2009; Torgler 2007). 
Thus, according to this logic, social trust is the foundation for cosmopolitanism. One cannot be a cosmopolitan without having general trust in others. Generalized trust reduces ethnocentrism (Mansfield and Mutz 2009). Generalized trust will allow one to identify with those beyond one’s local community (Kaltenthaler et al 2004). Generalized trust will also be bolstered by education as education is known to be positively correlated with social trust (Hainmueller and Hiscox 2006; Inglehart 1999; Kaltenthaler et al 2004).

Trust in others will condition how likely one is to want a trade policy that is based on protection or liberalization. Logically, those who are distrustful of others (and thus other countries) would want their government to be vigilant in the face of threats from economic engagement with other countries. Such individuals are more likely to favor protectionism. Those individuals who have a more positive view of human nature, i.e., believe that people can generally be trusted, will be more supportive of trade liberalization. This argument produces the central hypothesis to be tested in this paper, namely:

H1: The more trusting one is in others in general, the more support one will have for trade liberalization.

The rest of the paper is devoted to testing this hypothesis in relation to other existing arguments about the sources of support for and opposition to trade liberalization.

\section{Research Design}

To determine the factors that influence public support for trade liberalization, this study uses a cross sectional survey data set derived from World V alues Surveys (1995-1997). Individual-level data are examined for respondents. While there are 61 countries available in the 1995-1997 wave, there are six advanced industrial democracies possessing complete data for this study available ${ }^{1--A u s t r a l i a, ~ G e r m a n y, ~ N o r w a y, ~ S p a i n, ~}$ Switzerland, and the United States. In addition to conducting an aggregate analysis of the six countries, the availability of individual-level respondent data provides an opportunity for a more in-depth analysis. As a

\footnotetext{
${ }^{1}$ For example, the question we have operationalized as the dependent variable was not asked to respondents in the United Kingdom.
} 
result, we also seek to test our explanations of support for trade liberalization within each of the six countries as well. There were 9,166 respondents to the original survey in these six nations. We use a sub-sample of that, removing the don't know/refused responses and are left with 6,492 respondents for the analysis.

Given the limited nature of the dependent variable and the clustering of respondents within countries, we use logit regression with clustered standard errors by country to estimate the effects of social trust and other factors on attitudes toward trade liberalization. Primo, Jacobsmeier, and Milyo (2007) argue that the clustering of observations within units can produce methodological problems, primarily overestimating the statistical significance of unit level variables. Of the two common approaches for dealing with clustered data, clustered standard errors and multi-level modeling, they find that clustered standard errors offer a more direct and pragmatic solution, especially when the researcher is analyzing a large number of cases. Given the large number of observations in our analysis and our main emphasis on individual rather than country-level factors, we use clustered standard errors in our analysis.

To determine the relative impact of the independent variables in explaining the variance in our dependent variables, attitudes toward trade liberalization, we calculate the first differences using Gary King's Clarify program for Monte Carlo simulations. This means we calculate the change in the probability of a respondent indicating support of trade liberalization when the independent variable of interest is increased from its minimum to its maximum value while holding all remaining independent variables constant at their mean or median values.

\section{Measuring Support for Trade Liberalization (Dependent Variable)}

To gauge public support for trade liberalization, we turned to a question in the World Values Surveys (1995-1997) that asks whether individuals support trade. Specifically, the question asked: Do you think it is 
better if: 1. Goods made in other countries can be imported and sold here if people want to buy them; OR that: 2. There should be stricter limits on selling foreign goods here, to protect the jobs of people in this country. ${ }^{2}$

Trade liberalization has been identified as a leading element of increased economic integration throughout history (Cooper 1968; Lindert and Williamson 2001; Aninat 2002). For example, between 1820 and 1913, often considered the first global century, global trade jumped drastically owing to decreased transport costs (Rodrik 1997; Lindert and Williamson 2001). Trade has continued to maintain a prominent role in the integration of the international economy (Spero and Hart 1997). Furthermore, trade policy is extremely politically sensitive since it directly affects job security and wages — issues that are dear to the hearts of all citizens. Therefore, the above question should capture the nuances of trade liberalization.

Figure 1 provides a first glance at individual respondent attitudes toward trade liberalization both at the aggregate level (among the six nations) as well as within each of the six countries. In the aggregate, slightly more than one third (35.5\%) of individual respondents indicated a relatively supportive preference toward trade liberalization. This response indicates a rather under-whelming sense of support for trade liberalization, perhaps due to a number of factors including economic uncertainty brought about by the liberalization of product markets or even economic nationalist sentiments in response to international trade outcomes.

\section{[ Insert Figure 1 Here ]}

Alternatively, there is considerable variation at the national level. Specifically, support for trade liberalization was highest in Norway with $47.9 \%$ of respondents in support of trade liberalization. Germany and Switzerland follow Norway in terms of support levels with $47.4 \%$ and $42 \%$, respectively. On the other hand, support for trade liberalization was lowest among the six states in Australia (23.7\%), the United States $(27 \%)$, and Spain $(28.3 \%)$

\footnotetext{
${ }^{2}$ To make interpretation of the results easier, we recoded the dependent variable as follows: "Do you think it is better if: 1 . Goods made in other countries can be imported and sold here if people want to buy them; OR that 0 . There should be stricter limits on selling foreign goods here, to protect the jobs of people in this country."
} 


\section{Alternative Explanations (Independent Variables)}

Given the previous work on attitudes toward trade liberalization, we examine four explanations within our model.

The first focuses on an individual's level of general trust. Those who believe that others can be generally trusted will be more likely to support trade liberalization. This category is measured through one question asked in the World Values Survey. It asks: Generally speaking, would you say that most people can be trusted (1) or that you can't be too careful in dealing with people (0)? Respondents who state that most people can be trusted are hypothesized to also favor trade liberalization.

The second category of analysis focuses on economic utilitarian explanations for support of trade liberalization. This category has been examined most exhaustively in previous research. To instrument potential attitudes related to this category, we employ eight survey items from the 1995-1997 wave of the World V alues Survey. The first variable looks at financial satisfaction within the respondent's household. Specifically, it asks: How satisfied are you with the financial situation of your household? If "1" means you are completely dissatisfied on this scale, and "10" means you are completely satisfied, where would you put your satisfaction with your bousehold's financial situation? Those who are satisfied with their current household financial status are hypothesized to favor trade liberalization.

Our second economic utilitarian variable focuses on occupational categories. We predict that individuals from lower skilled occupations will be less supportive of opening trade to more competition. The question asks: In which profession/ occupation do you or did you work? While there are twelve categories provided, we have collapsed them into four for our analysis: management, white collar, blue collar and other. All four are entered as dummy variables in the model with other serving as the baseline. Individuals from blue collar occupations are hypothesized to be less supportive of trade liberalization.

Another economic utilitarian argument revolves around income. The question asks: Here is a scale of incomes. We would like to know in what group your household is, counting all wages, salaries, pensions and other incomes that 
come in. Respondents are asked to place themselves on a ten-point scale using country-specific income ranges. Those with lower incomes are predicted to be less willing to embrace trade liberalization.

Closely related to income, we include a variable measuring social class to test if those of perceived higher classes will be more likely to support trade liberalization. The question posits: People sometimes describe themselves as belonging to the working class, the middle class, or the upper or lower class. Would you describe yourself as belonging to the: lower class (0), working class (1), lower middle class (2), upper middle class (3), or upper class (4)?

Age is related to our economic utilitarian arguments within our study as older individuals are expected to be less tolerant of trade liberalization as they worry about their capability to recover from economic concerns. The survey question follows the individual stating their birthday and the surveyor stating, This means you are __years old.

Gender is our sixth economic utilitarian variable. Women are predicted to be more supportive than men of the government protecting those who lose out from market competition and consequently less accepting of trade liberalization. In the World Values Survey, gender is ascertained by simply asking the sex of the respondent: male (1) or female (0).

Union membership has been suggested by previous research to be an important consideration in shaping citizen attitudes toward trade liberalization with members being less supportive. The questions asks: Now I am going to read off a list of voluntary organizations; for each one, could you tell me whether you are a member (1) or not a member (0) of that type of organization: Labor union? The final economic utilitarian variable to consider is employment status. Individuals presently unemployed are expected to be less likely to support trade liberalization. The World V alues Survey asks individuals: Are you employed now or not? If not, are you retired/pensioned, a bousewife, student, or unemployed?

Our third explanatory category focuses on cosmopolitan variables and their potential influence on trade liberalization. Previous studies have found that an individual's geographic self-identification, level of education, and attitudes toward people of different races helped condition whether she opposed or supported 
freer trade. Those individuals who were more cosmopolitan in their global outlook were more in favor of freer trade. To account for these arguments, we utilize three variables from the World Values Survey. The first looks at how individuals view themselves in the world and is taken from a question that asks: To which of these organizational groups would you say you belong first of all? Respondents could choose from the locality or town where they live, the state or region of the country in which the live, the country as a whole, or the world as a whole.

The question related to education asks: What is the highest educational level that you have attained? Answers range from no formal education through university-level graduate with degree. The more educated the respondent, the more likely they are to support free trade. The final question looks at attitudes toward people of different races: On the list are various groups of people. Could you please sort out any that you would not like to have as neighbors: immigrants/foreign workers? If respondents are not willing to have immigrants as workers, we posit that they will be unwilling to support trade liberalizations. The more worldly their view, the more likely they are to support free trade.

The final category to examine looks at ideological dispositions of respondents through two questions. The first examines attitudes toward income equality in the world by asking: Where would you place yourself on a 1 10 scale if 1 represents "Incomes should be made more equal" and 10 represents "We need larger income differences as incentives for individual effort." Those who are accepting of income differences are hypothesized to support free trade. The second ideological variable aims to measure citizen attitudes toward competition through a similar tenpoint scale where the poles are represented by "Competition is good. It stimulates people to work hard and develop new ideas" and "Competition is harmful. It brings out the worst in people." Those who favor competition will also support trade liberalization.

Given that many of the independent variables ask respondents questions that could pull on the same underlying values, it is important to assure multicollinearity is not an issue for our model. Table 1 reports the correlations between all of our variables. The only worrisome correlation is between white and blue collar 
workers $($ rho $=.52)$. There is, however, still a substantial amount of variation. The correlation is expected to be fairly high, as well, given the dichotomous nature of the categorizations created from the survey question.

\title{
[ Insert Table 1 Here ]
}

Likewise, Table 2 presents the variance inflation factor scores for the independent variables included in the model. All are well below the typical threshold of 10 for excessive collinearity.

\author{
[ Insert Table 2 Here ]
}

Based on the correlation matrix and VIF scores, we do not believe collinearity is an issue for our model of analysis as specified.

\section{Results of the Analysis}

The logit regression analysis results for the pooled model are presented in Table 3.

\section{[ Insert Table 3 Here ]}

Looking at the results, we find varying levels of support for all four categories of our explanation in the hypothesized directions. Of most importance to our study, we find that our only measure of social trust proves to be significant at the .01 level, demonstrating that those who generally trust others support free trade. What this does is demonstrate the need for interjecting general measures of social trust into the discussion of trade liberalization.

When we consider the economic utilitarian category, we find two out of ten variables to be significant in the hypothesized direction. Class is positively related to trade liberalization at the .01 level and age is negatively associated at the .10 level. Consequently, younger individuals and those who perceive of themselves of being in a higher social class are more likely to support trade liberalization. Financial satisfaction, occupation categories, income, gender, union membership, and employment status are all found 
to be insignificant. Overall, this proves to be a weak performance by the category as the only two variables that are significant do not include the most explicit measures of economic satisfaction (financial satisfaction and income).

Our third category of explanation, focused on cosmopolitanism, finds mixed support as well with one of three variables to be significant. While there is no evidence of significance for immigrants as neighbors and geographic identity, education is significant at the .01 level. The more education a respondent has, the more likely they are to support trade liberalization.

The final category—ideology—also finds mixed support. The variable measuring attitudes toward income equality is significant at the .05 level. Those who are accepting of competition as a means for incentivizing individual efforts are more likely to support free trade. Attitudes toward competition, however, do not have a significant impact on trade liberalization.

Since we use logit, the coefficients we present in Table 3 do not portray the marginal effects of the independent variables on the dependent variable. To help present a fuller picture, we report the first differences of our significant variables in Table 3 as well. The first difference measures the probability of a respondent supporting trade liberalization when all independent variables are held at their mean or median (as appropriate) except for the variable of interest, which is moved from its minimum to maximum value. By doing this, we are able to assess the substantive effect of each independent variable to explaining variation in the dependent variable. When we examine our model, the most substantively significant variable shows to be education with a first difference of .196. This means that by increasing education from no formal education to college degree while holding all other variables at their means or medians, there is a $19.6 \%$ increase in the likelihood that a respondent will support free trade. Social class has the second largest impact by explaining $18.4 \%$ of the variance, followed by age (12.6\%), social trust $(12.2 \%)$, and income equality $(5.5 \%)$. While social trust is not the most impactful independent variable, we can show that failing to include this variable in studies examining attitudes toward trade liberalization excludes a measure that plays a significant role in shaping citizen opinion on the issue. 
While the aggregate model presents a clear picture, we still wish to examine how the model performs within each of the six countries. Since the pooled model controlled for country-specific effects by clustering the data, this provides an additional picture of how citizens determine their attitudes toward free trade. We began by providing a summary table in Table 4 that shows significant variables in each model. Variables that were significant in the pooled model are shaded.

\section{[ Insert Table 4 Here ]}

Like in the pooled model, we largely see support for all four categories of explanation. While there is variation between countries, social trust and education are consistently significant predictors in all with the exception of Spain. ${ }^{3}$

\section{Conclusion}

This paper was a study of how social trust shaped attitudes toward trade liberalization in a series of developed economies. Until now, generalized social trust has been ignored as a factor that could explain why some support trade liberalization and others oppose it. This paper was meant to break new ground by arguing that an individual's view of human nature is a basic and very important factor in how that individual views the international sphere. We argued that if a person does not generally trust other people, they are not likely to want to engage with others from foreign countries. Trade is one manner of foreign engagement. Thus, those who tend not to trust others, will be less likely to want to liberalize trade, and thus, at least in their mind, expose themselves to more contact with foreigners.

We tested this argument in a multiple regression analysis. Social trust was used as an independent variable alongside other common explanations of support and opposition to free trade, such as economic utilitarian explanations, explanations centered on the individual's level of cosmopolitanism, and explanations

\footnotetext{
${ }^{3}$ The country-specific results and first difference calculations are available on request from the corresponding author.
} 
that focus on ideology to explain support for trade liberalization. We found that social trust, along with education is the most consistent and important predictor of support for trade liberalization. Our prediction about the importance of social trust and its relationship to attitudes toward trade was upheld by the statistical analysis.

The theoretical implications of our findings is that scholars of public attitudes toward trade must now take into account the basic social psychology of the individual when they attempt to explain support and opposition to trade liberalization. It seems that there is a syndrome where educated individuals, with income, and higher social status are more in favor of trade liberalization. This could actually be part of the mix that produces more trusting individuals. We know that the more optimistic one is about one's future (which is correlated with economic security), the more likely one is to trust others (Ingelhart 1999).

What are the policy implications of the findings? They mean that policy-makers may have difficulty in changing the minds of large numbers of citizens when it comes to trade issues. People are largely predisposed to want more liberalized trade or not. Making economic pitches to the general public in support of more liberalized trade will probably not yield much in terms of swings in public opinion. 


\section{References}

Almond, Gabriel. 1950. The American People and Foreign Policy. New York: Harcourt, Brace.

Aldrich, John, Christopher Gelpi, Peter Feaver, Jason Reifler, and Kristin Thomas Sharp .2006. "Foriegin

Policy and the Electoral Connection." Annual Review of Political Science. 9: 477-502.

Aninat, Eduardo. 2002. "Surmounting the Challenges of Globalization." Finance and Development 39 (1): 3-11.

Baker, Andy. 2003. "Why is Trade Reform so Popular in Latin America? A Consumption-Based Theory of Trade Policy Preferences. World Politics. 55: 423-455

2005. "Who Wants to Globalize? Consumer Tastes and Labor Markets in a Theory of Trade

Policy Beliefs.” American Journal of Political Science. 49(4): 924-938.

Baron, Jonathon and Simon Kemp. 2004. "Support for Trade Restrictions, Attitudes, and Understanding of Comparative Advantage.” Journal of Economic Psychology, 25: 565-580.

Binning, Kevin. 2007. “'It's Us Against the World': How Distrust in Americans versus People-in-General Shapes Competitive Foreign Policy Preferences.” Political Psychology. 28(6): 777-799.

Brewer, Paul, Kimberly Gross, Sean Aday, and Lars Wilnat. 2004. "International Trust and Public Opinion About World Affairs.” American Journal of Political Science. 48(1): 93-109.

Brewer, Paul and Marco Steenbergen. 2002. "All Against All: How Beliefs about Human Nature Shape Foreign Policy Options.” Political Psychology. 23(1): 39-58.

Cardero, Maria Elena. 2000. “The Impact of NAFTA on Female Employment.” In Women's Empowerment and Economic Justice, Ed. Liliana De Pauli. New York: United Nations Development Fund For Women.

Citrin, Jack and John Sides. 2008. "Immigration and Imagined Community in Europe and the United States." Political Studies. 56(1): 33-56.

Cooper, Richard. 1968. The Economics of Interdependence. New York: McGraw-Hill Book Company.

Converse, Philip. 1964. “The Nature of Belief Systems in Mass Publics.” In Ideology and Discontent, David Apter, ed. New York: Free Press.

Duch, Raymond. 1993. "Tolerating Economic Reform: Popular Support for Transition to a Free Market in the Former Soviet Union.” American Political Science Review. 87, 3: 590-608.

Feldman, Stanley. 1988. "Structure and Consistency in Public Opinion: the Role of Core Beliefs and Values." American Journal of Political Science. 32(2): 416-440.

Gelpi, Christopher, Peter Feaver, Jason Reifler. 2005/2006. "Success Matters: Casualty Sensitivity and the War in Iraq." International Security. 40(3): 7-46

University Press. 2006. Paying the Human Costs of War. Princeton, N.J.: Princeton 
Hainmueller, Jens and Michael J. Hiscox. 2006. "Learning to Love Globalization: Education and Individual Attitudes toward International Trade." International Organization. 60 (2): 469-498.

Herreros, Francisco and Henar Criado. 2009. "Social Trust, Social Capital, and Perceptions of Immigration." Political Studies. 57(2): 337-355

Hurwitz, Jon and Mark Peffley. 1987. "How are Foreign Policy Attitudes Structured? A Hierarchical Model." The American Political Science Review 81 (4): 1099-1120.

Hurwitz, Jon, Mark Peffley, and Mitchell Seligson. 1993. "Foreign Policy Belief Systems in Comparative Perspective: The United States and Costa Rica." International Studies Quarterly. 37(3): 245-270.

Inglehart, Ronald. 1999. Modernization and Postmodernization: Cultural, Economic, and Political Change in 43 Societies. Princeton: Princeton University Press.

Jacob, Robert, Fabian Christandl, and Detlef Fechtenhauer. 2011. "Economic Experts or Laypeople? How Teachers and Journalists Judge Trade and Immigration Policies." Journal of Economic Psychology. 32, 5: 662-671.

Kaltenthaler, Karl, Ronald Gelleny, and Stephen Ceccoli. 2004. "Explaining Citizen Attitudes toward Trade Liberalization.” International Studies Quarterly 48: 829-851.

Kemp, Simon. 2008. "Lay Attitudes to Trade with Low-wage Countries." Judgment and Decision-making." 3: 335-343.

Lindert, Peter H., and Jeffrey Williamson. 2001. "Globalization and Inequality: A Long History.” Paper Delivered at the World Bank's Annual Bank Conference on Development Economics Barcelona, June25-27.

Maggiotto, Michael and Eugene Wittkopf. 1981. “American Public Attitudes Toward Foreign Policy. International Studies Quarterly. 25(4):601-301.

Mansfield, Edward and Diana Mutz. 2009. "Support for Free Trade: Self Interest, Sociotropic Politics, and Out-Group Anxiety.” International Organization. 63 (3): 425-457.

Mayda, Anna Maria. 2006. "Why are People more Pro-Trade than Pro-Migration?" Working Paper. Centre for Research and Analysis of Migration.

Mayda, Anna Maria, and Dani Rodrik. 2005. "Why are Some People More Protectionist Than Others?" European Economic Review. 49(6): 1393-1430.

Mazur, Jay. 2000. “Labor’s New Internationalism.” Foreign Affairs 79 (1): $79-93$.

Moon, Bruce. 1996. Dilemmas of International Trade. Boulder: Westview Press.

O’Rouke, Kevin H., and Richard Sinnott. 2001. “The Determinants of Individual Trade Policy Preferences: International Survey Evidence.” Brookings Trade Forum 1 (1): 157-206.

Ozler, Sule. 2000. “Exporting and Female Share of Employment.” World Development 28: 1239-1248.

Page, Benjamin and Robert Shapiro. 1983. "Effects of Public Opinion on Policy." American Political Science Review. 77(1):175-190. 
1992. The Rational Public: Fifty Years of Trends in American Policy Preferences. Chicago: University of Chicago Press.

Peffley, Mark and Jon Hurwitz. 1993. "Models of Attitude Constraint in Foreign Affairs." Political Behavior 15 (1): 61-90.

Primo, David, Matthew Jacobsmeier, and Jeffrey Milyo. 2007. "Estimating the Impact of State policies and Institutions with Mixed-Level Data." State Politics and Policy Quarterly. 17(4): 446-459.

Rodrik, Dani. 1997. Has Globalization Gone Too Far? Washington, DC: Institute for International Economics.

Shamir, Michal and Asher Arian. 1994. "Competing Values and Policy Choices: Israeli Public Opinion on Foreign and Security Affairs.” British Journal of Political Science. 24: 249-271.

Scheve, Keneth and Matthew Slaughter. 2001a. Globalization and the Perception of American Workers. Washington, D.C.: Institute for International Economics.

Scheve, Keneth and Matthew Slaughter. 2001b. "What Determines Individual Trade-policy Preferences?” Journal of International Economics.54: 267-292.

Spero, Joan, and Jeffrey Hart. 1997. The Politics of International Relations. New York: St. Martin’s Press.

Stolper, Wolfgang and Paul Samuelson. 1941. "Protection and Real Wages." The Review of Economic Studies. 9(1): 58-73.

Torgler, Benno. 2007. "Trust in International Organizations: An Empirical Investigation Focusing on the United Nations." The Review of International Organizations. 3(1): 65-93.

Trentmann, Frank. 1998. "Political Culture and Political Economy: Interest, Ideology, and Free Trade." Review of International Political Economy. 5(2): 217-251.

Wittkopf, Eugene. 1990. Faces of Internationalism: Public Opinion and American Foreign Policy. Durham: Duke University Press.

World Bank. 1997. World Development Report 1997_The State in a Changing World. Washington, DC: World Bank. 
Figure 1: Support for Trade Liberalization

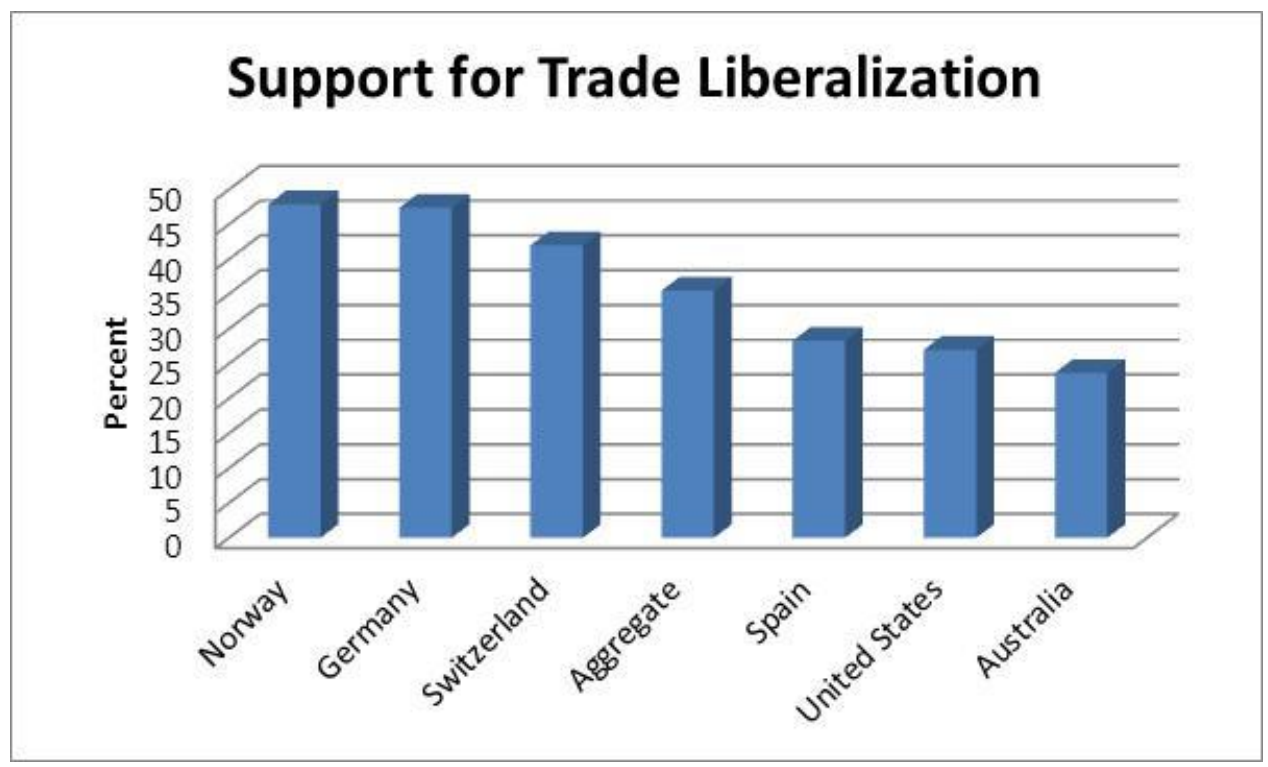




\section{Table 1: Correlations between Variables}

\begin{tabular}{|c|c|c|c|c|c|c|c|c|c|c|c|c|c|c|c|c|c|}
\hline & $\begin{array}{l}\text { Trade } \\
\text { Lib. }\end{array}$ & $\begin{array}{l}\text { Social } \\
\text { Trust }\end{array}$ & $\begin{array}{l}\text { Fin. } \\
\text { Satisfy }\end{array}$ & Mgmt. & $\begin{array}{l}\text { Wt. } \\
\text { Collar }\end{array}$ & $\begin{array}{l}\text { Bl. } \\
\text { Collar }\end{array}$ & Income & Class & Age & Gender & $\begin{array}{l}\text { Union } \\
\text { Member }\end{array}$ & Unemployed & $\begin{array}{c}\text { Immigrant } \\
\text { as } \\
\text { Neighbor }\end{array}$ & $\begin{array}{l}\text { Geographic } \\
\text { Identity }\end{array}$ & Education & $\begin{array}{l}\text { Income } \\
\text { Equality }\end{array}$ & Competition \\
\hline Trade Lib. & 1 & & & & & & & & & & & & & & & & \\
\hline Social Trust & 0.1605 & 1 & & & & & & & & & & & & & & & \\
\hline Mgmt. & -0.0077 & 0.0088 & 0.0094 & 1 & & & & & & & & & & & & & \\
\hline Wt. Collar & 0.0326 & 0.0286 & 0.0149 & -0.2274 & 1 & & & & & & & & & & & & \\
\hline Bl. Collar & -0.0454 & -0.0074 & -0.0189 & -0.2271 & -0.5126 & 1 & & & & & & & & & & & \\
\hline Income & 0.1238 & 0.1201 & 0.2685 & -0.0016 & -0.0194 & 0.0042 & 1 & & & & & & & & & & \\
\hline Class & 0.1665 & 0.1471 & 0.3028 & 0.0137 & 0.0018 & -0.0255 & 0.3554 & 1 & & & & & & & & & \\
\hline Age & -0.0919 & -0.0237 & 0.1452 & 0.0035 & -0.0219 & -0.0229 & -0.1656 & -0.041 & 1 & & & & & & & & \\
\hline Gender & 0.0091 & 0.0008 & -0.0074 & 0.0915 & -0.0999 & 0.1386 & 0.0051 & -0.008 & -0.0065 & 1 & & & & & & & \\
\hline $\begin{array}{c}\text { Union } \\
\text { Member }\end{array}$ & 0.0191 & 0.1009 & 0.0384 & -0.0031 & 0.0008 & 0.03 & 0.1407 & 0.0041 & -0.039 & 0.0196 & 1 & & & & & & \\
\hline Unemployed & -0.0344 & -0.0593 & -0.1535 & -0.0103 & -0.016 & -0.007 & -0.0992 & -0.1125 & -0.0658 & 0.0027 & -0.0328 & 1 & & & & & \\
\hline $\begin{array}{c}\text { Immigrant as } \\
\text { Neighbor } \\
\end{array}$ & -0.056 & -0.0498 & 0.0036 & -0.0259 & -0.0003 & 0.0086 & -0.031 & -0.0238 & 0.0861 & -0.0172 & 0.0024 & 0.0014 & 1 & & & & \\
\hline $\begin{array}{c}\text { Geographic } \\
\text { Identity } \\
\end{array}$ & 0.0759 & -0.0282 & 0.0141 & -0.008 & 0.0051 & -0.009 & 0.0736 & 0.074 & -0.0471 & -0.0019 & -0.0314 & -0.0241 & -0.0325 & 1 & & & \\
\hline Education & 0.2012 & 0.1958 & 0.1028 & 0.0124 & 0.0078 & 0.0052 & 0.3153 & 0.3693 & -0.2537 & 0.0129 & 0.0877 & -0.081 & -0.0825 & 0.119 & 1 & & \\
\hline $\begin{array}{l}\text { Income } \\
\text { Equality }\end{array}$ & 0.0622 & -0.0063 & 0.0976 & 0.0163 & 0.0061 & 0.012 & 0.1078 & 0.1487 & -0.0346 & 0.0232 & -0.0275 & -0.0438 & 0.0005 & 0.0258 & 0.1282 & 1 & \\
\hline Competition & -0.0131 & -0.0285 & -0.0757 & -0.0251 & 0.0051 & 0.0128 & -0.1015 & -0.0881 & -0.0615 & 0.0052 & 0.039 & 0.055 & 0.0046 & -0.0276 & -0.0781 & -0.0851 & 1 \\
\hline
\end{tabular}


Table 2: Variance Inflation Factor Scores

\begin{tabular}{cc} 
Variable & VIF \\
\hline Blue Collar & 1.68 \\
White Collar & 1.64 \\
Class & 1.35 \\
Education & 1.34 \\
Income & 1.31 \\
Management & 1.29 \\
Financial Satisfaction & 1.21 \\
Age & 1.15 \\
Social Trust & 1.07 \\
Income Equality & 1.04 \\
Union Member & 1.04 \\
Unemployed & 1.04 \\
Gender & 1.04 \\
Competition & 1.03 \\
Geographic ID & 1.02 \\
Immigrant as Neighbor & 1.01 \\
\hline Mean VIF & $\mathbf{1 . 2 0}$
\end{tabular}


Table 3: Logistic Regression Results-Pooled Model

Dependent Variable-Trade Liberalization

\begin{tabular}{|c|c|c|c|}
\hline $\begin{array}{l}\text { Independent } \\
\text { Variables }\end{array}$ & Coef. & S.E. & $\begin{array}{l}\text { First } \\
\text { Diff. }\end{array}$ \\
\hline Social Trust & $.535^{* * *}$ & .083 & .122 \\
\hline Financial Satisfaction & .015 & .012 & \\
\hline Management & -.213 & .284 & \\
\hline White Collar & -.033 & .185 & \\
\hline Blue Collar & -.266 & .166 & \\
\hline Income & .021 & .034 & \\
\hline Class & $.203 * * *$ & .041 & .184 \\
\hline Age & $-.007 *$ & .004 & .126 \\
\hline Gender & .073 & .063 & \\
\hline Union Membership & -.027 & .124 & \\
\hline Unemployed & -.068 & .272 & \\
\hline Immigrant as Neighbor & -.299 & .187 & \\
\hline Geographic ID & .094 & .055 & \\
\hline Education & $.113^{* * *}$ & .033 & .196 \\
\hline Income Equality & $.028^{* *}$ & .011 & .055 \\
\hline Competition & .011 & .022 & \\
\hline Pseudo R ${ }^{2}$ & .0597 & & \\
\hline Log Likelihood & -4216.558 & & \\
\hline Log Likelihood $X^{2}$ & 503.41 & & \\
\hline $\mathrm{N}$ & 6,492 & & \\
\hline
\end{tabular}

Note: Figures are unstandardized coefficients shown alongside standard errors clustered by country. ${ }^{*} \mathrm{p}<.1$; ${ }^{* *} \mathrm{p}<.05 ;{ }^{* * *} \mathrm{p}<.01$. 
Table 4: Country-Specific Results

\begin{tabular}{|c|c|c|c|c|c|c|}
\hline Variable & Australia & Germany & Norway & Spain & Switzerland & United States \\
\hline Social Trust & $\checkmark$ & $\checkmark$ & $\checkmark$ & & $\checkmark$ & $\checkmark$ \\
\hline $\begin{array}{c}\text { Financial } \\
\text { Satisfaction }\end{array}$ & & & & & & \\
\hline Management & & & $\checkmark$ & & & \\
\hline White Collar & & & $\checkmark$ & & & \\
\hline Blue Collar & & $\checkmark$ & & & & \\
\hline Income & $\checkmark$ & & & & $\checkmark$ & \\
\hline Class & & & & & & \\
\hline Age & & $\checkmark$ & & & & \\
\hline Gender & & $\checkmark$ & & & & $\checkmark$ \\
\hline Union Membership & & & & & & $\checkmark$ \\
\hline Unemployed & & $\checkmark$ & & & & \\
\hline $\begin{array}{c}\text { Immigrant as } \\
\text { Neighbor }\end{array}$ & & & $\checkmark$ & $\checkmark$ & & $\checkmark$ \\
\hline Geographic ID & & $\checkmark$ & & $\checkmark$ & $\checkmark$ & \\
\hline Education & $\checkmark$ & $\checkmark$ & $\checkmark$ & & $\checkmark$ & \\
\hline Income Equality & & $\checkmark$ & & & & \\
\hline Competition & & & & $\checkmark$ & & \\
\hline
\end{tabular}

